\title{
A rare case of ovarian granulosa cell tumour in an adolescent girl with secondary amenorrhea and virilisation
}

\author{
Arun Nayak, Meenal Sarmalkar*, Madhuri Mehendale, Neha Singh, Shrutika Shah
}

\begin{abstract}
Department of Obstetrics \& Gynaecology, Lokmanya Tilak Municipal Medical College \& General Hospital, Sion,
\end{abstract} Mumbai, Maharashtra, India

Received: 22 August 2015

Revised: 6 September 2015

Accepted: 8 September 2015

\author{
*Correspondence: \\ Dr. Meenal Sarmalkar, \\ E-mail: meenal.sarmalkar@gmail.com
}

Copyright: (C) the author(s), publisher and licensee Medip Academy. This is an open-access article distributed under the terms of the Creative Commons Attribution Non-Commercial License, which permits unrestricted non-commercial use, distribution, and reproduction in any medium, provided the original work is properly cited.

\begin{abstract}
Sex cord stromal ovarian tumors account for about $5-8 \%$ of all ovarian malignancies. Granulosa cell tumor is an estrogen secreting low grade malignant tumor and is seen in women of all ages with $2 \%$ bilaterality. Based upon histology, these neoplasms can be classified as adult and juvenile Granulosa cell tumors. Pre-pubertal lesions present clinically with sexual pseudo precocity whereas post-pubertal lesions present with menstrual irregularities or secondary amenorrhea or postmenopausal bleeding. This case report presents a rare case of Granulosa cell tumor with clinical presentation mimicking virilizing ovarian neoplasm in a 19 year old girl with history of abdominal swelling, secondary amenorrhea and virilization since one year duration. Clinical examination revealed a 20-22 weeks size abdominal mass, cystic in consistency, arising from pelvis and CT scan suggested presence of mucinous cystadenoma with solid areas with suspected malignancy. Exploratory laparotomy with right salpingo-oophorectomy was performed with staging as tumor was found confined to ovary with no involvement of other ovary or any other pelvic organ or peritoneum. Therefore, disease was staged as stage 1A. Histopathological examination confirmed the presence of Granulosa cell tumor with fibrothecomatous areas.
\end{abstract}

Keywords: Granulosa cell tumor, Secondary amenorrhea, Virilizing ovarian neoplasm

\section{INTRODUCTION}

Granulosa cell tumors have been classified as sex cord stromal ovarian tumors with low malignant potential. These lesions have been noted in women of all age group with only $5 \%$ incidence in pre-pubertal girls. Most of the affected patients present classically with all clinical symptoms and signs associated with hyperestrogenism like precocious puberty, abnormal uterine bleeding, secondary amenorrhea, postmenopausal bleeding depending upon age of patient at onset of disease. Most of these tumors are detected usually in stage 1 with $90 \%$ ten year survival rate. But they have shown tendency to recur 5-30 years after initial diagnosis. ${ }^{1}$ More commonly, these tumors show features of hyperestrogenism, but in rare cases, clinical presentation may differ and patient may have hirsutism or even virilization secondary to excess production of androgenic steroids. ${ }^{2}$

\section{CASE REPORT}

A 19 yrs old unmarried girl came to gynaecology OPD with complaints of secondary amenorrhea since 1 year, increased body hair growth, hoarseness of voice since 6 months and abdominal swelling associated with mild intermittent pain in lower abdomen since 4 months. She gave history of being investigated previously for similar complaints two months back and was advised USG that was suggestive of a large $12 \times 7.5 \mathrm{~cm}$ complex cystic tuboovarian mass with internal septations. She achieved 
menarche at the age of 13 years which was followed by irregular prolonged menstrual cycles. There was no history of weight gain, change in appetite, thyroid disorders, skin hyper pigmentation, nipple discharge and symptoms due to intracranial lesions. There was no family history of genital or breast malignancies. On clinical examination, there was increased facial and body hair with no evidence of acanthosis nigricans, thyroid swelling or nipple discharge or skin hyper pigmentation and purplish striae/bruises. On per abdomen examination, cystic mass of 20-22 weeks size arising from pelvis with minimal tenderness was noted. There was no guarding or rigidity. On local examination, there was no clitoromegaly and external genitalia appeared normal. On per rectal examination, mass was felt higher up and not felt separately from uterus with no rectal involvement or nodularity. CT scan abdomen and pelvis was done which showed a well-defined $18.3 \times 16.5 \times 8.6 \mathrm{~cm}$ cystic lesion with two lobulated component of $5.5 \times 9.2 \times 6.3 \mathrm{~cm}$ with heterogeneous enhancing component suggestive of mucinous cystadenoma with solid component most probably of malignant origin (shown in Figure 1).

Hence, causes for secondary amenorrhea and virilization other than ovarian tumor like pregnancy; PCOS, thyroid disorder, hyperprolactinemia, adrenal tumors and late onset adrenal hyperplasia were ruled out. In presence of rapid onset virilization, complex ovarian mass with high testosterone levels, presence of a virilizing ovarian tumor was suspected. Exploratory laparotomy was performed. Intraoperatively, a large 20x25 cm, smooth, lobulated, solid mass arising from right ovary with intact capsule was noted (Shown in Figure 2 and 3). Uterus, left fallopian tube and left ovary were macroscopically normal. There was no evidence of metastasis to other pelvic structures, omentum, peritoneum, lymph nodes or other intra-abdominal organs.

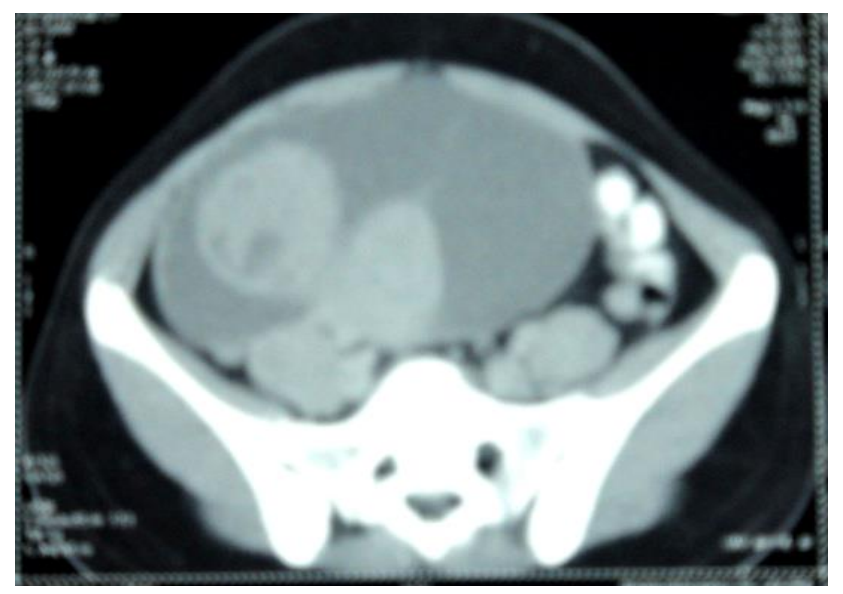

Figure 1: CT image of abdominopelvic mass.

She was further evaluated with laboratory investigations including hormonal profile and ovarian tumor markers.
Table 1: Laboratory investigations of patient.

\begin{tabular}{|lll|}
\hline Investigations & $\begin{array}{l}\text { Patient's } \\
\text { level }\end{array}$ & $\begin{array}{l}\text { Normal } \\
\text { range }^{3}\end{array}$ \\
\hline Serum FSH level & $0.52 \mathrm{mIU} / \mathrm{ml}$ & $5-20 \mathrm{mIU} / \mathrm{ml}$ \\
\hline Serum LH level & $11.4 \mathrm{mIU} / \mathrm{ml}$ & $5-20 \mathrm{mIU} / \mathrm{ml}$ \\
\hline Serum TSH level & $3.36 \mu \mathrm{IU} / \mathrm{ml}$ & $\begin{array}{l}0.4-4.5 \\
\mu \mathrm{IU} / \mathrm{ml}\end{array}$ \\
\hline Serum Prolactin level & $8.72 \mathrm{ng} / \mathrm{ml}$ & $1-20 \mathrm{ng} / \mathrm{ml}$ \\
\hline Serum Estradiol level & $51.0 \mathrm{pg} / \mathrm{mL}$ & $20-400 \mathrm{pg} / \mathrm{dl}$ \\
\hline $\begin{array}{l}\text { Serum Total } \\
\text { Testosterone }\end{array}$ & $327 \mathrm{ng} / \mathrm{dL}$ & $20-80 \mathrm{ng} / \mathrm{dl}$ \\
\hline Serum DHEAS level & $172 \mu \mathrm{g} / \mathrm{dL}$ & $80-350 \mu \mathrm{g} / \mathrm{dl}$ \\
\hline CA-125 level & $5.6 \mathrm{U} / \mathrm{ml}$ & $5-35 \mathrm{U} / \mathrm{ml}$ \\
\hline
\end{tabular}

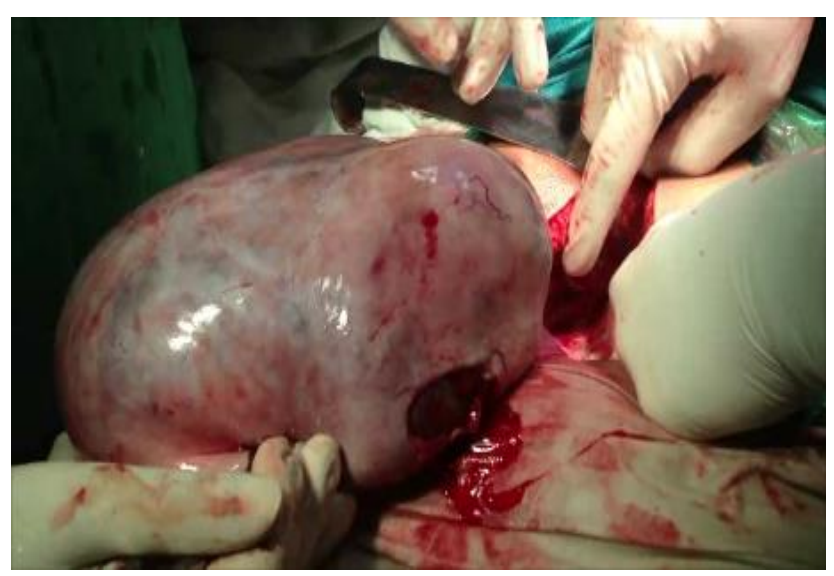

Figure 2: Gross appearance of ovarian tumor.

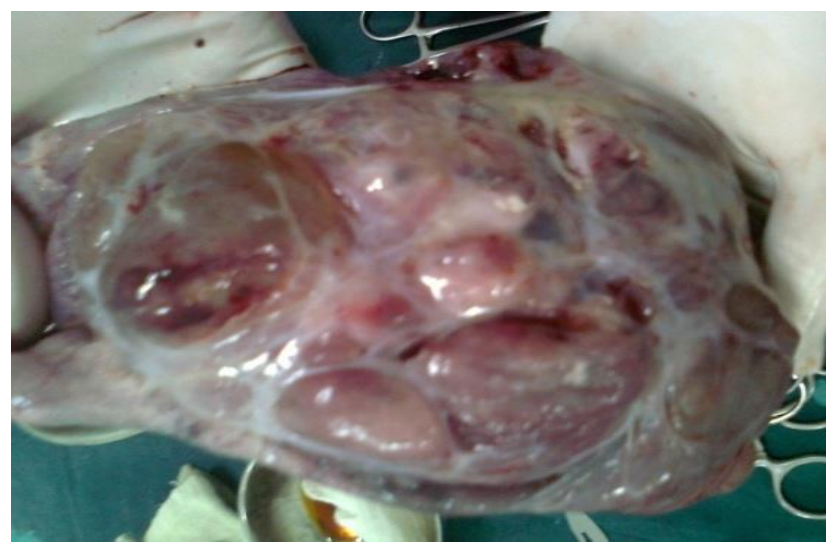

Figure 3: Cut section of ovarian tumor.

As per surgical staging (stage I) and need for fertility preservation, unilateral salpingo-oophorectomy was done. Histopathological examination was found to be consistent with diagnosis of Granulosa cell tumor ovary with characteristic "Call Exner's" bodies with coffee bean nuclei with fibrothecomatous areas (Shown in Figure 4). 

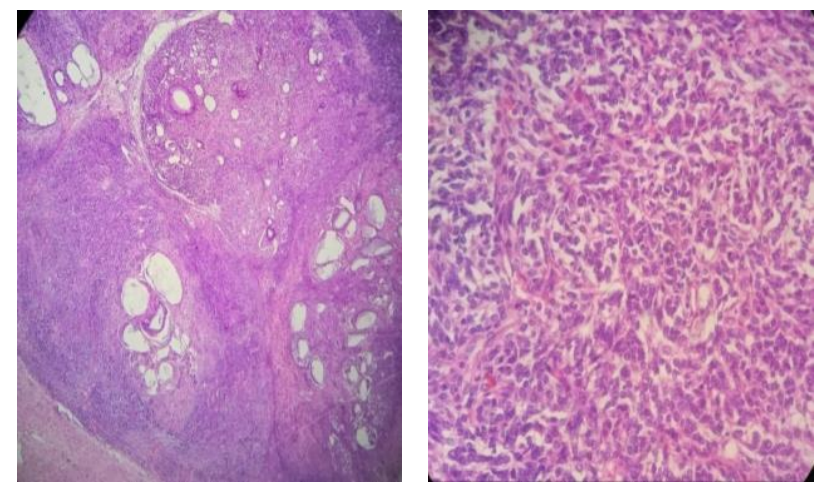

Figure 4: Histopathological appearance of ovarian tumor (4.1- showing granulosa cells arranged in macro follicular pattern; 4.2- showing Call Exner bodies with fibrothecomatous areas).

Postoperative course was uneventful and had menses after 26 days of surgery. Serum testosterone level normalized two months later $(42 \mathrm{ng} / \mathrm{dL})$ with serum inhibin B level of $9.8 \mathrm{pg} / \mathrm{ml}$ with normal ultrasound. Patient was followed up at three months and found to be free from her all previous symptoms including virilization.

\section{DISCUSSION}

Granulosa stromal cell tumors are classified as sex cord stromal tumors. They include Granulosa cell tumors, thecomas, and fibromas. Granulosa cell tumors are seen in women of all ages and have low malignant potential. Bilaterality is seen in only $2 \%$. On gross appearance, they have smooth encapsulated, lobulated surface with size ranging from few millimetres to $20 \mathrm{~cm}$ or more. Classical histopathological features include round Granulosa cell with scanty cytoplasm and "coffee bean" appearance of nuclei and Call-Exner's bodies with their resemblance to primordial follicles along with stroma similar to theca. In children and adolescents, they are often cystic. Functional Granulosa cell tumors commonly present with features of hyperestrogenism. Clinical presentation varies depending upon age of onset like in prepubertal girls- sexual pseudo precocity, in women of reproductive age-menstrual irregularities, secondary amenorrhea , cystic endometrial hyperplasia and in postmenopausal womenpostmenopausal bleeding due to endometrial hyperplasia $\left(25-50 \%\right.$ cases) and endometrial carcinoma (in 5\%). ${ }^{1}$ However, they can rarely manifest with virilizing features due to hyper secretion of androgenic steroids. One of the explanations for androgenic presentation of this tumor may be because of tumor being non-functional in nature and causing stromal tissue stimulation to produce excess androgens. ${ }^{3}$ Only few cases of androgenic Granulosa cell tumors have been reported worldwide. Tumor markers for GCTs include serum Estradiol level \& Inhibin being helpful in diagnosis and follow up post operatively with detection of tumor relapse. Most of the patients are detected in stage I with long term survival of more than $90 \%$ whereas $70 \%$ in stage II-IV disease. ${ }^{1}$
A large multicentric retrospective study was done by Lee et al to evaluate clinicopathologic characteristics and prognostic factors of GCTs. This study included 113 patients with GCTs ovary and 102 patients were detected to have adult type disease and 86 had FIGO stage I disease. Recurrence was seen in 10 and staging was found to be most important factor associated with disease free survival. $^{4}$

A rare case of juvenile GCT in a 17 year old girl was reported by Reddy et al in year 2014. She presented with complaints of secondary amenorrhoea and pelvic mass and as she had stage I disease, unilateral salpingooophorectomy was done. ${ }^{5}$

Most of the androgenic juvenile GCTs are solid in consistency with lack of classical histopathological picture of adult type GCTs. Kumar et al reported a very rare case of androgenic cystic juvenile GCT in a young girl with pelvic mass associated with secondary amenorrhea and virilization. Unilateral salpingooophorectomy was performed with surgical staging. Histopathological examination of tumor was suggestive of juvenile GCT with cystic areas of luteinization. ${ }^{6}$

\section{Treatment}

Staging laparotomy with debulking of tumor by salpingooophorectomy (where fertility is to be preserved) or by total hysterectomy with bilateral salpingo-oophorectomy is the mainstay of treatment of stage 1a tumors. Patient with advanced metastatic disease need chemotherapy after cytoreduction. Limited data is available regarding use of chemotherapeutic agents in stage III/IV disease. Four-six cycles with BEP regimen have been tried successfully for treatment of metastatic disease and recurrences. Radiotherapy is reserved only for recurrent disease in selected group of patients. Use and efficacy of hormonal agents like progestins, antiestrogens, aromatase inhibitors are not proven yet due to limited available data. ${ }^{2,3}$ As these tumors are known for relapse, long term follow up is necessary for early detection.

\section{CONCLUSION}

Sex cord stromal tumors are rare ovarian neoplasms with few reported cases of Granulosa cell tumors. High index of suspicion is required to deal with GCTs with uncommon presentation like virilization. Appropriate Surgical and histopathological staging is essential for diagnosis and management of these tumors. Early diagnosis and tumor debulking improves survival rates.

\section{Funding: No funding sources \\ Conflict of interest: None declared \\ Ethical approval: Not required}




\section{REFERENCES}

1. Berek SJ. Ovarian and Fallopian Tube Cancer. In: Berek SJ, eds. Berek \& Novak's Gynecology. $15^{\text {th }}$ ed. Philadelphia, PA: Lippincott Williams \& Wilkins. 2013:1520-22.

2. Stephen AC. Ovarian Cancer, Fallopian Tube Carcinoma, and Peritoneal Carcinoma. In: DeVita VT, Lawrence TS, Rosenberg SA, eds. DeVita, Hellman, and Rosenberg's Cancer: Principles \& Practice of Oncology. $10^{\text {th }}$ ed. Philadelphia, PA: Lippincott Williams \& Wilkins. 2015:1094-95.

3. Fritz MA. Hirsutism. In:Fritz MA, Speroff L, eds. Clinical Gynecologic Endocrinology and Infertility. $8^{\text {th }}$ ed. Philadelphia, PA: Lippincott Williams \& Wilkins. 2011:546-548.
4. Lee I, Choi C, Hong D, Song J. Clinicopathologic characteristics of granulosa cell tumors of the ovary: a multicenter retrospective study. J Gynecol Oncol. 2011;22:188-95.

5. Reddy K, Pavithra D, Ragini R, Pallavi S. Juvenile granulosa cell tumour: a rare clinical entity. Int $\mathbf{J}$ Reprod Contracept Obstet Gynecol. 2014;3:1150-54.

6. Kumar B, Singh R, Bharathi K. Virilizing Cystic Juvenile Granulosa Cell Tumour of the Ovary: A Case Report. J Clin Diagn Res. 2014;8:3-4.

Cite this article as: Nayak A, Sarmalkar M, Mehendale M, Singh N, Shah S. A Rare Case of Ovarian Granulosa cell Tumor in Adolescent girl with Secondary amenorrhea and Virilization: a case report. Int J Reprod Contracept Obstet Gynecol 2015;4:16536. 